\title{
A natureza na preservação do patrimônio cultural paulista: a contribuição de Aziz Nacib Ab'Saber
}

Nature in the preservation of São Paulo's cultural heritage: the contribution of Aziz Nacib Ab'Saber

https://doi.org/10.1590/1982-02672020v28d2e26

\section{SIMONE SCIFONI'}

https://orcid.org/0000-0001-8027-2740

Universidade de São Paulo / São Paulo, SP, Brasil

RESUMO: Um dos exemplos mais significativos de avanços promovidos nas políticas públicas de patrimônio cultural dos anos 1980 foi a consolidação da ideia de natureza como seu objeto de atuação. Grutas, serras, morros, rios, florestas, ilhas, parques urbanos, dentre outros bens naturais, passaram a compor a lista do patrimônio tombado do estado de São Paulo. Essa experiência, que teve sua origem 50 anos atrás, ainda é marcada na atualidade por inúmeras dificuldades de compreensão do objeto em si e sua relação com os valores culturais. Nesse sentido, o presente artigo busca apresentar e colocar em debate os elementos centrais dessa prática institucional, apontando para o papel e as contribuições do geógrafo Aziz Nacib Ab'Saber na consolidação do trabalho dentro no órgão de preservação do patrimônio cultural do estado de São Paulo. $O$ caminho para a discussão passa, inicialmente, pela compreensão das origens e dos marcos legais da proteção desse objeto, com destaque para o legado da década de 1980, no fortalecimento e expansão da proteção da natureza como patrimônio cultural a partir da construção de princípios conceituais. Ao final, procurase apontar para a atualidade e problemática do tema frente às políticas públicas em curso.

PALAVRAS-CHAVE: Patrimônio natural. Políticas de patrimônio. Tombamento.

\begin{abstract}
1. Geógrafa, mestra e doutora em Geografia pela Universidade de São Paulo. Atuou em instituições públicas de proteção do patrimônio cultural como o Instituto de Patrimônio Histórico e Artístico Nacional (Iphan), Condephaat/SP e Conselho Municipal de Patrimônio Cultural de São Bernardo do Campo. Fundadora e membro da Rede Paulista de Educação Patrimonial (Repep). Membro do Icomos-Brasil. Vice-diretora do Centro de Preservação Cultural CPC/USP. E-mail: <simone.scifoni@ gmail.com>
\end{abstract}

ANAIS DO MUSEU PAULISTA São Paulo, Nova Sèrie, vol. 28, 2020, p. 1 -30 d2 e26 
ABSTRACT: One of the most significant examples of advances in public policy for cultural heritage in the 1980s was the widespread acceptance of the notion that nature should be part of its scope. Caves, mountains, hills, rivers, forests, islands, urban parks and other natural assets were added to the list of heritage sites of the State of São Paulo. This experience, which began 50 years ago, continues to be marked by some major difficulties in understanding the object itself and its relationship with cultural values. In that sense, this paper aims to present and debate the key elements of this institutional practice, highlighting the role and contributions of geographer Aziz Nacib Ab'Saber towards solidifying the work of the cultural preservation agency of the State of São Paulo. At first, the path to this discussion involves an understanding of the origins and legal frameworks for protecting of this object, with a special spotlight on the legacy of the 1980s, the strengthening and expansion of the protection of nature as cultural heritage, starting with the development of conceptual principles. At the end, it aims to describe the current scenario and the problematics of the topic in light of current public policy.

KEYWORDS: Natural heritage. Heritage policy. Heritage listing. 


\section{INTRODUÇÃO}

Embora as práticas institucionais de preservação do patrimônio natural tenham mais de 50 anos de existência dentro do órgão estadual paulista Condephaat $-^{2}$ e tenham sido produto de uma experiência rica e pioneira que resultou em cerca de 40 áreas naturais tombadas no Estado de São Paulo, ainda hoje há muito desconhecimento e incompreensão a respeito do tema. Nos discursos oficiais dos gestores públicos e dos representantes nesse conselho, constata-se a dificuldade de compreensão do objeto em si - patrimônio natural -, como também no que diz respeito aos valores culturais atribuídos a ele.

A relutância vem do fato de que ainda predomina dentro do órgão uma visão cartesiana e fragmentada que separa as duas dimensões do objeto, a cultura e a natureza, impedindo de compreendê-las como uma unidade dialética, portanto, um todo, contraditório e único. Essa visão dualista tem criado obstáculos à continuidade do trabalho sob o argumento de que há sobreposição de competências e que a proteção da natureza caberia tão somente aos órgãos ambientais. Trata-se de argumentação que desconhece ou ignora a trajetória das políticas públicas na incorporação dos novos objetos e ampliação conceitual em patrimônio e também ignora a própria legislação competente. É importante lembrar que a Constituição Federal de 1988, em seu artigo 216, define patrimônio cultural incluindo como objetos os "sítios de valor paisagístico, ecológico e científico", portanto, o que se chama hoje de patrimônio natural.

Assim sendo, o patrimônio natural é, em primeiro lugar, um objeto da natureza, testemunho de processos ecológicos e do meio físico, o que significa que tem dinâmica própria, muito embora sob ação e influência dos fatores sociais. Considere-se aqui, como exemplo, um parque urbano, formado por um conjunto de vegetação que, por conta de processos fisiológicos das plantas e aqueles relacionados ao funcionamento do ecossistema, tem uma dinâmica de crescimento vegetal, floração ou frutificação articulada a determinadas condições ambientais e de sazonalidade.

Mas o patrimônio natural não é somente isso. Essa natureza, em determinados momentos, pode ser anunciada como suporte físico que compõe a memória coletiva, portanto, fator de formação identitária de determinados grupos sociais. Considere-se novamente aquele mesmo parque urbano, agora como um equipamento de uso coletivo, intensamente apropriado pelos grupos sociais de moradores de bairros próximos, um lugar da vida cotidiana na cidade, demandado pela população.

Nesse sentido, como objeto de uso e fruição social e incorporada como componente essencial da memória coletiva, essa natureza é representada,
2. Conselho de Defesa do Patrimônio Histórico, Arqueológico, Artístico e Turístico do Estado de São Paulo. 
anunciada e compreendida como patrimônio natural em sua dupla dimensão: como fragmento de importância biológica, ecológica ou física e, por outro lado, como suporte de memória, ação e identidade de grupos sociais. Nesse caso, atribui-se a ela um valor cultural, associando-se novo conteúdo que não se restringe apenas ao fato de ser testemunho de processos ecológicos e do meio físico. A natureza torna-se, assim, concorrentemente, um bem cultural, testemunho da vida social, apropriado por uma ação cultural. Trata-se da criação de mais uma categoria que compõe o conjunto do patrimônio cultural, junto com as demais, como é o caso do edificado, o imaterial, o arqueológico. Dessa maneira, o patrimônio natural não se opõe, mas compõe o patrimônio cultural em sua noção ampliada.

É justamente pela necessidade de esclarecer essas questões em um quadro em que ainda restam dúvidas, inconsistências ou incompreensões que se torna importante retomar e enfatizar o legado da experiência pioneira de incorporação da natureza como patrimônio cultural, a qual teve os anos 1980 como seu momento máximo. A construção de diretrizes conceituais para abordagem desse objeto, a ampliação das tipologias de patrimônio natural tombado, a expansão quantitativa e representativa no território, a aprendizagem sobre o desenho da preservação, ou seja, das poligonais de área tombada, e o atendimento de demandas sociais são exemplos de parte desse legado que se busca aqui apresentar e destacar.

O artigo inicia procurando situar a gênese da ideia de patrimônio natural como parte da políitica pública de patrimônio cultural no Estado de São Paulo, para depois concentrar o olhar para a contribuição do geógrafo Aziz Nacib Ab'Saber em dois momentos: como conselheiro representante do Departamento de Geografia da USP, na década de 1970, momento em que conduziu processos de tombamentos de áreas naturais e a partir dos quais formulou os fundamentos conceituais para tratamento desse novo objeto; e como presidente do órgão, em um mandado de apenas cinco meses que resultou na intensa expansão e consolidação das práticas de tombamento de áreas naturais.

Além de Aziz Ab'Saber, ao longo de mais de vinte anos de atuação, entre as décadas de 1980 e 1990, foram muitos os geógrafos e as geógrafas que contribuíram para esse trabalho com o patrimônio natural. Foram conselheiros e conselheiras, representantes dos Departamentos de Geografia das três universidades estaduais paulistas, como também técnicos e técnicas que compuseram a equipe de áreas naturais, juntamente com outros profissionais das áreas de Biologia, Geologia e Antropologia. Não cabe aqui, nesse momento, trazer uma listagem de nomes desses profissionais que estiveram presentes na instituição, mas, sim, partir da contribuição de Aziz Ab'Saber para colocar em evidência o papel e importância da Geografia para o campo da proteção do patrimônio cultural. A formação 
geográfica possibilita lidar com a compreensão dos fenômenos sociais, culturais e naturais de forma articulada como uma totalidade, assim como é capaz de produzir um olhar que transita desde a escala espacial local em direção a outras dimensões ampliadas, como as escalas regional e nacional. Foi justamente esse olhar interescalar que permitiu a Aziz Ab'Saber propor a proteção, via instrumento do tombamento, de importantes áreas naturais do Estado de São Paulo.

Ao final, o artigo busca atualizar o debate situando a problemática desse objeto em um momento de políticas públicas neoliberais voltadas a flexibilizar e desregulamentar as normativas de tombamento para ajustar o patrimônio aos interesses do econômico e da produção da cidade como negócio.

\section{AS ORIGENS DO PATRIMÔNIO NATURAL NOS ANOS 1970}

Muito embora as práticas de tombamento de áreas naturais tivessem ocorrido desde os primeiros anos de funcionamento do Condephaat, em 1969, a noção propriamente dita de patrimônio natural ainda não se encontrava presente naquele momento. $\bigcirc$ que se chama hoje de patrimônio natural aparecia naquele momento inicial, de criação do órgão de duas diferentes formas: como monumento natural ou como recanto paisagístico. Isso foi resultado da forma como se concebeu a legislação daqueles primeiros momentos de atuação do órgão. Entretanto, foi a partir do trabalho de Aziz Ab'Saber, como membro do conselho, na gestão de 1976 a 1978, que houve a ampliação desse entendimento e a sua formulação conceitual. Portanto, coube a ele dar nova forma a algumas experiências que eram pontuais e fragmentadas.

Retomando as origens, constata-se o tombamento do Bosque dos Jequitibás, situado em Campinas, como marco inaugural da constituição desse novo objeto de atuação no órgão. Na primeira gestão do conselho, de 1969-1970, instituída logo depois da criação da legislação, ${ }^{3}$ o Condephaat tombou 13 bens na sua grande maioria edifícios ligados às elites, como palacetes, solares, palácios, mas também dois núcleos urbanos e bens móveis como obras de arte, e, entre todos, um parque urbano, o Bosque dos Jequitibás. ${ }^{4}$ Trata-se de uma das mais importantes áreas verdes da cidade de Campinas, pelo fato de constituir um fragmento de vegetação nativa, remanescente das matas que originariamente tinham ampla distribuição pelo interior do território paulista, o qual foi preservado como forma de proteção de uma cabeceira de rio, nascente que se encontra dentro do parque. É um dos principais parques da cidade, situado no interior do tecido urbano, local de ampla visitação, lazer, turismo e uso social. Sendo assim, além de área verde
3. Constituição Estadual de 1967 , artigo 128 , cria o Condephaat.

4. Cf. Rodrigues (2000). 
5. Resolução SC de 9 abr. 1070 , artigo $1^{\circ}$.

6. Decreto-Lei Federal $\mathrm{n}$. 25 de 1937 , artigo $1^{\circ}$, parágrafo $2^{\circ}$

7. Lei Estadual n. 10.247 de 22 out. 1968, artigo $2^{\circ}$.

8. Decreto Federal n. 3, de 13 fev. 1948. de importância ecológica, o bosque se destacava pelo componente afetivo, de memória coletiva e identidade local dadas pelo uso e fruição social.

Tombado como monumento natural paisagístico, conforme redação da Resolução de Tombamento, ${ }^{5}$ o Bosque dos Jequitibás inaugurou as possibilidades dadas pelo corpus legal existente à época. De um lado, o ato estava amparado na legislação maior, de âmbito federal que organizou a proteção do chamado patrimônio histórico e artístico nacional, o Decreto-lei n 25, de 1937. ${ }^{\circ}$ Esse dispositivo legal tornou os monumentos naturais passíveis de tombamento, uma vez que os equiparou ao patrimônio histórico e artístico nacional. Por outro lado, a própria legislação estadual de São Paulo também estabelecia essa possibilidade, uma vez que a lei que complementou a criação do Condephaat em 19687 definiu como competência do órgão a defesa dos recantos paisagísticos.

Assim, o monumento natural está nas origens do que chamamos hoje de patrimônio natural e tem identificado, em sua definição legal, os atributos de valor estético, histórico ou científico, ${ }^{8}$ bem como a noção de recantos paisagísticos que enfatiza a ideia de lugares de beleza cênica. É incorporando esses dois sentidos que ocorrem os primeiros tombamentos das áreas naturais, durante a década de 1970, sendo ao todo sete áreas tombadas, conforme identifica-se no quadro 1.

Quadro 1 - Patrimônios naturais tombados pelo Condephaat (década de 1970)

\begin{tabular}{|l|l|}
\hline Bem tombado (município) & Ano (resolução de tombamento) \\
\hline Bosque dos Jequitibás (Campinas) & 1970 \\
\hline Parque das Monções (Porto Feliz) & 1972 \\
\hline Faixa de mata ao longo do antigo Caminho do Mar (Cubatão) & 1972 \\
\hline Pedreira de Varvito (ltu) & 1974 \\
\hline Parque da Independência (Capital) & 1975 \\
\hline Horto Florestal de Rio Claro (Rio Claro) & 1977 \\
\hline Maciço da Jureia (lguape) & 1979 \\
\hline
\end{tabular}

Fonte: Scifoni, 2006.

A Pedreira de Varvito, situada em ltu, é outro exemplo importante desse período inicial da década de 1970, que traz semelhante abordagem a partir da noção de monumento natural paisagístico. Apesar do processo ter sido aberto em 1969 e, portanto, ser iniciativa contemporânea ao tombamento do Bosque dos Jequitibás, sua tramitação foi mais longa, tendo sido finalizada apenas em 1974. 


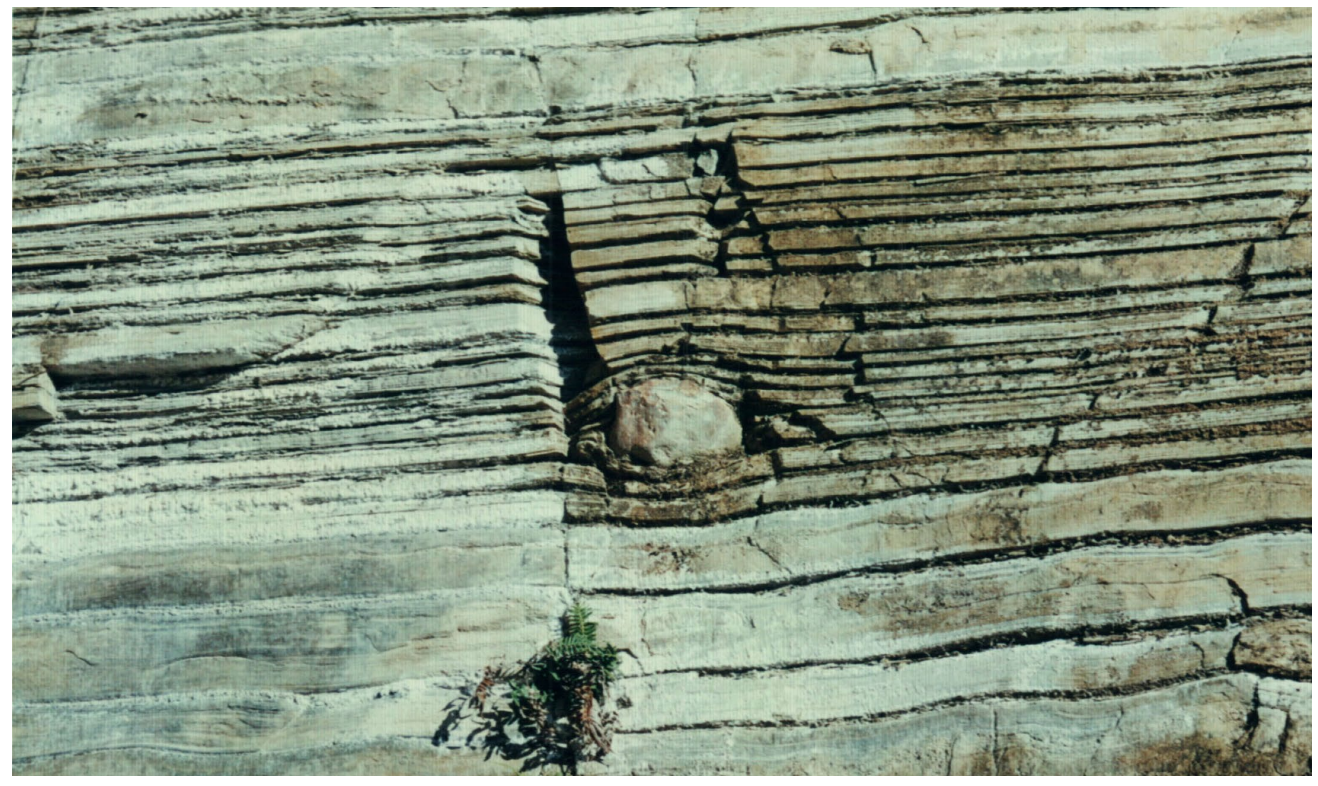

Figura 1 - Detalhe das camadas de sedimentos da rocha na Pedreira do Varvito, 2011 . Foto: arquivo pessoal.

$\bigcirc$ pedido partiu do conselheiro Vinicius Stein Campos que solicitou o tombamento de uma pedreira em vias de desativação. A justificativa para tal destacava o interesse didático-científico e turístico, tendo em vista a área abrigar um mostruário de rochas de excepcional valor como testemunho de glaciações pretéritas no continente, portanto, remanescente de paleoclimas. A estrutura foi formada no passado geológico a partir de lagos temporários localizados à frente de geleiras e alimentados pelas águas do degelo. A variação das camadas de sedimentos depositados nesses lagos, ora mais claros ou mais escuros, ora mais delgados ou mais espessos, conferiram à rocha varvito uma qualidade estética única, ou seja, a característica rítmica resultado da oscilação entre períodos mais frios, alternados a períodos mais quentes (figura 1). A importância científica aliada à qualidade estética do conjunto de rochas enquadrava-se no escopo legal, tanto como monumento natural como recanto paisagístico. Mas a justificativa para o tombamento atrelou, também, o papel histórico da rocha como material construtivo característico da identidade arquitetônica e urbanística da cidade, sendo usado como revestimento e calçamento, ${ }^{9}$ mostrando a relação indissociável entre natureza e história, característica desse primeiro período. Ou seja, é sob o amparo da legislação incidente que esses casos pontuais de tombamento têm, em comum, a ampliação do olhar dos conselheiros para o que se chamava de patrimônio histórico. Apesar de Rodrigues ${ }^{10}$ apontar esse primeiro período do órgão como caracterizado por práticas que permaneciam nos limites da ortodoxia do Sphan, ${ }^{11}$
9. Processo Condephaat $\mathrm{n}$. 9.884/1969.

10. Cf. Rodrigues (2000).

11. Serviço do Patrimônio Histórico e Artístico Nacional, atual Iphan (Instituto do Patrimônio Histórico e Artístico Nacional), órgão federal de proteção do patrimônio criado em 1937. 
12. Kamide; Rodrigues (1998).

13. Cf. Chaui (2013). reproduzindo a atribuição de valor unicamente a partir da materialidade, atrelando o valor histórico à história da arquitetura, colocando o foco nos ciclos econômicos e tratando os centros históricos como um único monumento, percebe-se, também, contraditoriamente, os avanços e ineditismos, resultado de posturas diferenciadas que possibilitam ampliar a visão em relação ao que a autora chamou de tradicionalismo da área preservacionista.

Exemplo disso é o conselheiro Vinicius Stein Campos, representante do então Serviço de Museus Históricos, vinculado à Secretaria de Cultura, Educação e Turismo. Ao mesmo tempo em que defendia o caráter cívico-educativo do patrimônio, em seu sentido mais conservador e sintonizado aos ideais da ditadura militar naquele ano de 1969, contraditoriamente foi o autor de vários pedidos de tombamento de áreas naturais, como já visto, o Bosque dos Jequitibás, e ainda, a Pedreira de Varvito, o Parque da Independência e o Horto Florestal de Rio Claro. Ainda que vários desses bens tenham o caráter de exaltação cívica, a novidade ficava por conta desse olhar que incorporava a natureza ao que se considerava histórico, como um objeto único, aquele se denomina hoje de bem cultural.

O Parque das Monções é exemplar desse olhar. Ele é um desses lugares ligado à construção do mito fundador da identidade bandeirante paulista e que foi tombado pela sua importância como um porto natural, às margens do Rio Tietê. Esse ancoradouro foi ponto de partida dos colonos portugueses, no século $\mathrm{XVI}$, em busca de índios a serem escravizados e, mais tarde, no século XVIII, foi o lugar de onde partiram as expedições fluviais comerciais conhecidas como Monções. ${ }^{12} \bigcirc$ caráter cívico-didático desse tombamento, ou seja, o de reforçar uma identidade com o mito bandeirante, idealizado e representado sem a violência inerente a sua ação na colonização portuguesa, possibilita ler esse objeto como semióforo, nos termos discutidos por Chauí, ${ }^{13}$ ou seja, como um lugar provido de significado e força simbólica, celebrado como signo de poder e prestígio, não ligado necessariamente a sua materialidade. Entretanto, a força simbólica, nesse caso, alimenta-se da materialidade do lugar, pois não se trata de espaço neutro qualquer, mas das margens de um importante rio, que tem um papel central na história da apropriação do território paulista.

Nesse sentido, além de semióforo, esse objeto tombado é uma área natural por excelência, formada pelas barrancas e pelo Rio Tietê, pela mata ciliar exuberante que o acompanha e alguns elementos construtivos, como a escadaria que dá acesso da antiga rua do porto ao rio, pelo caminho que acompanha à margem, pelo belvedere e monumento aos bandeirantes erguido nos anos 1920. O paredão de rocha que se encontra na margem direita, de 
formato bastante íngreme e constituído por rocha sedimentar arenítico-calcárea é de excepcional beleza, sendo nele instalada uma espécie de gruta dedicada à imagem de Nossa Senhora de Lourdes. O bem cultural descreve-se, assim, como um objeto único, no qual história e natureza são indissociáveis na composição do chamado valor cultural, ainda que ligado a conteúdos cívicos.

Assim, dentro desse sentido original, muitos dos bens naturais foram vistos associando-se natureza à história da transformação do território paulista, sem o estabelecimento de distinções ou oposições entre essas duas dimensões. Tratava-se da compreensão do papel da natureza no processo histórico de transformação do território.

Mesmo assim, percebe-se duas diferentes situações em relação ao quadro de áreas naturais tombadas como produto da relação história-natureza.

Em primeiro lugar, alguns bens tombados foram resultado da atribuição de valor a um objeto que constitui uma área natural em si mesma, como se viu no caso do Bosque dos Jequitibás, Parque das Monções e Pedreira de Varvito, e será visto adiante no tombamento do Horto de Rio Claro e Maciço da Jureia.

Em segundo lugar, há outros bens que se apresentavam como objetoscomplemento, ou seja, áreas naturais contíguas ou de extensão a edifícios ou construções de interesse histórico ou artístico.

Esse é o caso, por exemplo, das matas ao longo do Caminho do Mar, tombadas em 1972, como paisagem envoltória ou complemento da antiga estrada Caminho do Mar e seus monumentos comemorativos, projetados por Victor Dubugras. Essa área natural formada pelas vertentes da Serra do Mar recobertas de mata nativa compunha a ambiência necessária para a leitura da importância desse bem, ou seja, a do desafio de superação, tanto dos 800 metros de altitude entre litoral e planalto, como das declividades acentuadas da serra. Ao longo do processo verificam-se diversas manifestações de profissionais do patrimônio, entre eles, Benedito Lima de Toledo, Aureliano Leite e Carlos Lemos, destacando a importância paisagística da vegetação e da Serra do Mar e a necessidade de incluir esses elementos para compor o objeto do tombamento. ${ }^{14}$ Outro exemplo nessa categoria de objeto-complemento é o da área verde situada aos fundos do Museu Paulista, que foi incluída no tombamento do "sítio onde se deu o Grito do Ipiranga", 15 local atualmente conhecido como Parque da Independência. A área core essencial definida pela Resolução de Tombamento é composta pelos terrenos onde se encerra o Monumento à Independência, indo até a edificação do Museu Paulista, chamada de Gleba 1. Incluiu-se nesse tombamento, também, um bosque que foi resultado da implementação de experimento botânico utilizando espécies nativas e que foi definido como Gleba 2.
14. Processo Condephaat $\mathrm{n}$. $123 / 1972$.

15. Resolução SC de 2 abr. 1975. 
16. Cf. Rodrigues (2000).

17. Decreto-Lei estadual $n$. 2, de 15 ago. 1969 estabelecia que as ilhas do litoral paulista, assim como a faixa de quatro quilômetros paralela à orla marítima como zona de interesse turístico, submetida à restrições de aprovação de loteamentos, construções ou instalação de propaganda que contrariassem padrões de ordem estética, que deveriam ser estabelecidos por decreto do governador, a partir de iniciativa do Condephaat.
De maneira geral, constata-se que todos esses primeiros tombamentos eram ações pontuais e esporádicas, minoritários em relação às ações dentro do órgão, sendo que, dos 113 tombamentos efetuados nessa primeira década, apenas oito incluíam as áreas naturais e, dessas, pelo menos dois são áreas verdes que são extensão e complemento de patrimônio arquitetônico tombado. Isso demostra que, apesar desse pioneirismo na incorporação da natureza como parte do patrimônio cultural, as ações ainda eram bastante incipientes.

\section{CONTRIBUIÇÕES DE AB'SABER COMO CONSELHEIRO (1976-1978)}

O quadro anteriormente apresentado e debatido somente começou a mudar a partir da contribuição de Ab'Saber, nesse primeiro momento como membro do conselho deliberativo do órgão, na gestão de 1976 a 1978.

A participação do geógrafo se deu a partir da mudança de gestão da então Secretaria de Cultura, Ciência e Tecnologia, em 1976, que passou a ser conduzida por José Mindlin, tendo como presidente do Condephaat o arquiteto Nestor Goulart Reis Filho. Em 1976, o conselho passou de 9 para 13 conselheiros, tendo sido ampliada a representação, incluindo-se a partir daí mais dois conselheiros ligados a unidades da Universidade de São Paulo (USP), um representante da Conferência Nacional dos Bispos do Brasil (CNBB) e mais um da Comissão de Artes Plásticas ligada à própria Secretaria de Cultura. ${ }^{16}$

Como professor do Departamento de Geografia da Faculdade de Filosofia, Letras e Ciências Humanas da Universidade de São Paulo e especialista na área de geomorfologia, além de temas ligados a fitogeografia e ecologia, Ab'Saber foi responsável por dar densidade conceitual ao debate sobre tombamento de áreas naturais, ultrapassando os limites de uma compreensão que, até então, era predominantemente baseada no caráter estético, fundada em valores como excepcionalidade e monumentalidade. $\bigcirc$ geógrafo não somente reorientou a análise dos processos de tombamento em curso, como também foi responsável pela formulação de diretrizes conceituais para as áreas naturais.

Exemplo disso constata-se no processo de tombamento do Maciço da Jureia, situado em lguape, litoral sul paulista. $\bigcirc$ parecer de abertura de processo de tombamento, em 1973, destacava as características de excepcionalidade das praias que compunham a região da Jureia-Itatins, fazendo menção à legislação de proteção das belezas naturais de interesse turístico, instituída a partir de 1969.17 
A dificuldade desse novo objeto, uma área natural de grande extensão, se colocou desde o início em relação a delimitação e compreensão sobre qual objeto, de fato, se tratava. O pedido de tombamento fazia menção a uma extensa área de praias, em função das ameaças de instalação de um megaempreendimento, o Condomínio Rio Verde, projeto que previa ocupação para 74 mil habitantes em um trecho de planície costeira habitado secularmente por grupos caiçaras. $\bigcirc$ Maciço da Jureia inaugura no Condephaat um fato que se tornou marcante na década seguinte, 1980, o tombamento de áreas naturais como demanda social. O pedido foi encaminhado pela Sociedade de Ecologia e Turismo de Itanhaém, assinado por Ernesto Zwarg Junior, uma das mais importantes lideranças do movimento ambientalista que, naquela época, começava a surgir. Em 1973, ano em que foi solicitado o tombamento do maciço, existiam no estado, de acordo com Urban, ${ }^{18} 12$ entidades ambientalistas atuantes, entre elas a de Ernesto Zwarg, uma das pioneiras, pois foi criada na década de 1950. A intenção do movimento era preservar a Jureia, transformando-a em um parque público, segundo a autora. Coube a Ab'Saber definir mais claramente o objeto de tombamento. $\bigcirc$ autor entendia tratar-se essencialmente daquele maciço costeiro saliente, mergulhado em uma paisagem de planície arenosa, faixas de restinga e praias, possuindo uma individualidade morfológica e geológica própria e densamente recoberto por vegetação nativa da floresta atlântica. ${ }^{19}$ Originariamente como parte do conjunto Serra do Mar em seu momento de formação no passado geológico, o Maciço da Jureia desligou-se morfologicamente do conjunto, permanecendo em condição de paleo-ilha florestada. Para o autor, o maciço tinha uma particularidade, dado o fato de que se encontrava dividido em dois núcleos, separados pelo vale do Rio Verde. Isolado pela ausência de estradas, essa parte do litoral paulista permaneceu, nas palavras do autor, como um estoque de natureza tropical, último dos grandes remanescentes da natureza tropical atlântica. Em seu parecer de tombamento, Ab'Saber delimitou o maciço como uma espécie de reserva de proteção integral, a partir da cota altimétrica de 20 metros, incluindo na poligonal de tombamento o curso do Rio Verde, até a sua foz. A decisão do conselho em dezembro de 1977 aprovando o tombamento antecedia, portanto, a criação da Estação Ecológica da Jureia. Em telegrama enviado ao Condephaat, o Secretário Especial do Meio Ambiente, Paulo Nogueira Neto, agradeceu ao órgão os esforços que foram importantes para justificar a criação da estação ecológica. ${ }^{20}$

Ab'Saber também teve uma importante atuação como conselheiro relator no processo de tombamento do Horto de Rio Claro, na cidade de mesmo nome. O pedido foi encaminhado, em 1974, por Vinícius Stein Campos, diretor do Serviço de Museus Históricos da Secretaria de Cultura e conselheiro do
18. Cf. Urban (2001)

19. Cf. Ab'Saber (1978).

20. Processo Condephaat $\mathrm{n}$. 00306/1973. 
21. Processo Condephaat n. $00428 / 1974$.

Figura 2 - Aspecto do interior e da área de lazer do Horto de Rio Claro, 2012. Foto: Stepan N. Chaihinian. Fonte: Xavier; Scifoni (2012, p. 34).
Condephaat, em razão do alegado abandono das instalações do Museu do Eucalipto, situado dentro do Horto Florestal.

Ao contrário das áreas naturais tombadas anteriormente, em que o caráter natural aparecia associado aos remanescentes de vegetação nativa, como no Caminho do Mar e no Bosque dos Jequitibás, o pedido de tombamento de um conjunto arbóreo composto essencialmente de vegetação exótica suscitou uma série de indagações e dúvidas. $\bigcirc$ horto fazia parte de um conjunto de 18 áreas criadas pela Companhia Paulista de Estradas de Ferro no interior do estado, como parte de uma política pioneira de reflorestamento, tendo em vista a extensão do desmatamento pelo território e o alto custo do carvão mineral como combustível para as ferrovias. Entretanto, desse conjunto de áreas reflorestadas, apenas o horto de Rio Claro funcionou como centro de pesquisas e experimentação na aclimatação de várias espécies australianas de eucalipto, iniciativa coordenada pelo engenheiro agrônomo Edmundo Navarro de Andrade.

O parecer de tombamento elaborado por $\mathrm{Ab}^{\prime} \mathrm{Saber}^{21}$ argumentou que a área representava o maior e único arquivo vivo sobre eucalipto do mundo, o que The conferia um valor científico excepcional para a história da silvicultura nacional, destacando, também, o papel relacionado ao turismo e lazer, já que o horto é a maior área verde da cidade, amplamente usada pela população local como área de convivência, recreação e fruição (figura 2). Ao compreendê-lo como arquivo vivo de espécies vegetais, Ab'Saber abria a perspectiva de pensar a área como patrimônio genético, portanto, vinculando-o à noção de natureza e permitindo seu enquadramento como área natural, destacando seu conteúdo histórico.

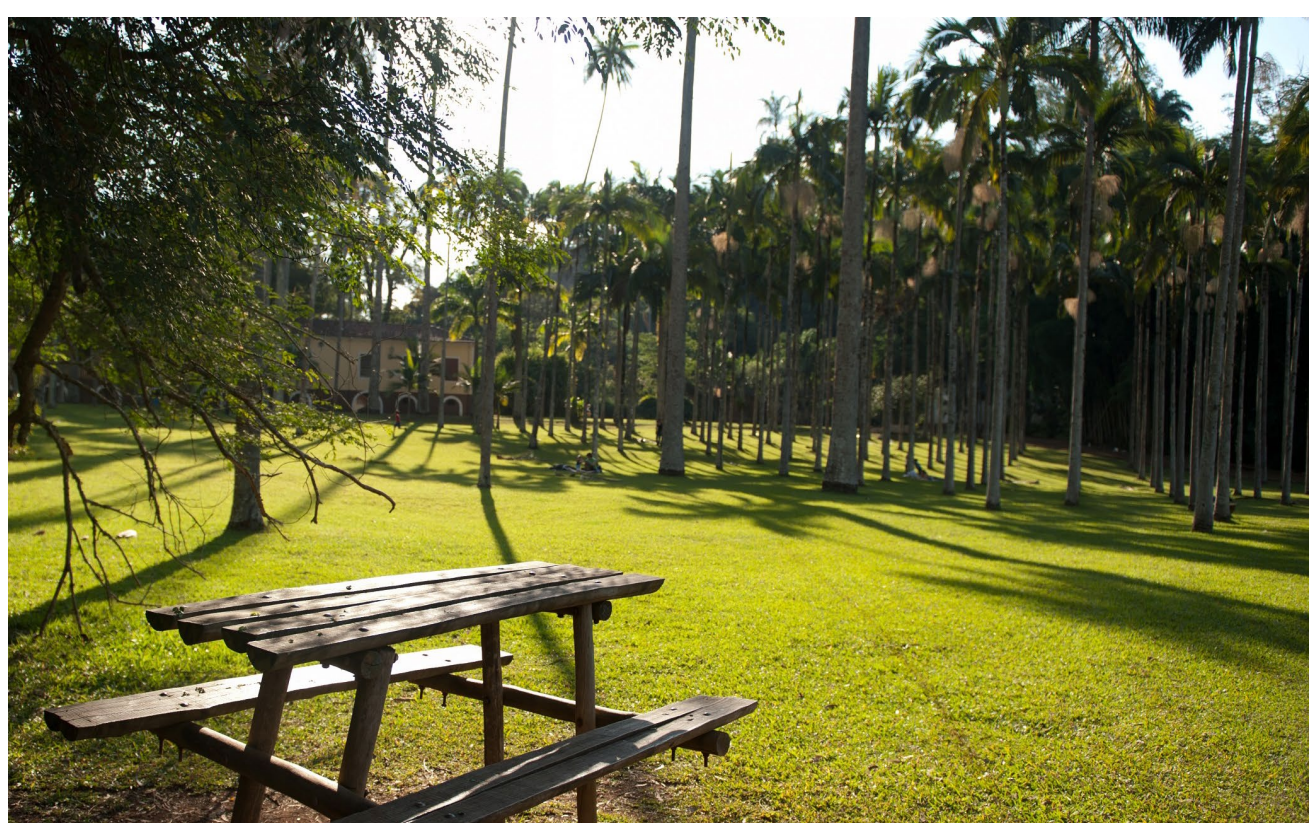


Naquele momento, a dificuldade de enquadramento do Horto Florestal entre as áreas naturais tombadas levou o arquiteto diretor do serviço técnico a questionar no conselho a ausência de critérios de seleção para o que ele chamou de "bens culturais alusivos à nossa flora ou a nossa arquitetura paisagística". ${ }^{22}$ Se a legislação possibilitava a inclusão desses novos objetos como parte do que era chamado patrimônio histórico a partir da noção de monumento natural e de recanto paisagístico, era preciso, por outro lado, contar com diretrizes gerais que pudessem orientar e nortear as ações. Nesse sentido, o arquiteto solicita a abertura de um processo que passa a tramitar como "Plano Sistematizador das Abordagens das Reservas Florestais e de Pontos de Atração Turísticas da Serra do Mar e Planícies Litorâneas". ${ }^{23}$

É nesse contexto que Ab'Saber estabelece sua contribuição, anexando ao processo um documento debatido em reunião do conselho no item de pauta intitulado "Proposta de proteção e valorização do patrimônio natural" ${ }^{24}$ Tratase de iniciativa pioneira não só em São Paulo, mas no país, de estabelecimento tanto de uma fundamentação conceitual para a preservação do patrimônio natural, como de diretrizes operacionais para identificá-lo.

Essa proposta se vale da noção de patrimônio natural que, naquele momento, estava em consolidação internacionalmente em função dos trabalhos encaminhados pela Unesco, por meio da Convenção do Patrimônio Mundial, Natural e Cultural, de 1972, guardando, entretanto, profundas diferenças de compreensão em relação as diretrizes elaboradas por Ab'Saber. ${ }^{25}$

Uma delas diz respeito a relação entre patrimônio natural e cultural. Apesar do documento internacional, em texto original de 1972, unificar as tutelas do patrimônio natural e cultural sob a mesma convenção, em seus artigos $1^{\circ}$ e $2^{\circ}$ são estabelecidas definições e critérios gerais de identificação de forma separada para os bens naturais e os culturais. Para o patrimônio natural, a leitura do artigo da convenção permite agrupar esses critérios em três instâncias de valor: o valor estético, expresso nas paisagens notáveis e de extraordinária beleza natural ou pela sua condição de exceção; o valor ecológico, vinculado à conservação da biodiversidade; e o valor científico, ligado ao conhecimento sobre a história da formação do planeta. $^{26}$

As diretrizes propostas por Ab'Saber, no entanto, se baseavam na experiência institucional do Condephaat, de incorporação da natureza como um objeto de atuação e como parte da noção de patrimônio histórico, superando, portanto, essa visão dualista contida na convenção da Unesco. ${ }^{27}$ Mas essa proposta do autor deve ser entendida, também, como parte de uma conjuntura de mudanças no órgão e de renovação conceitual possibilitada pela introdução da noção de patrimônio ambiental urbano, conforme apresenta Rodrigues. ${ }^{28}$ Essa noção, além de aproximar o patrimônio da experiência de vida coletiva e da
22. Ibid.

23. Processo Condephaat $\mathrm{n}$. $20.089 / 1976$.

24. Ata n. 287 de Reunião do Condephaat, 14 jun. 1976

25. Cf. AB'Saber (1977).

26. Cf. Scifoni (2006).

27. O que mais tarde a própria Unesco fez em suas Diretrizes Operacionais para Implementação do patrimônio Mundial, ao fundir o artigo $1^{\circ}$, relativo aos critérios para o patrimônio cultural e o artigo $2^{\circ}$, relativo ao patrimônio natural em um único conjunto de critérios para reconhecimento, fruto essencialmente da consolidação da categoria paisagem cultural que demandou essa unificação.

28. Cf. Scifoni (op. cit.). 
dimensão do cotidiano, propiciou outro desdobramento na medida em que considerou a importância de bens e artefatos para além de si mesmos, incorporando o ambiente no qual foram produzidos e que com ele guardavam relação, reforçando a perspectiva de se pensar a natureza como parte do patrimônio cultural.

Foi o conhecimento de Ab'Saber sobre a realidade brasileira, a partir de sua experiência de pesquisa em geomorfologia, fitogeografia e ecologia, que permitiu ao autor propor nesse documento a adoção de três critérios essenciais de identificação do patrimônio natural. Tais critérios também se distinguem das orientações que a Unesco adotava na convenção. Isso porque, enquanto a Unesco adota parâmetros muito rígidos de integridade, que leva a sua associação à lugares de natureza selvagem, para o autor a identificação e a seleção do que deveria ser protegido como patrimônio natural não implicava somente os atributos dos bens em si mesmos, ou seja, suas qualidades estéticas, ecológicas ou científicas. Era preciso considerar o caráter relativo dessa seleção, levando em conta o contexto de urbanização e industrialização a que estas áreas estavam submetidas, portanto, os fatores de risco sobre os bens.

O primeiro critério dizia respeito à necessidade de preservar o que ele chamou de "áreas críticas e ecologicamente estratégicas". 29 Enquadram-se nesses critérios os remanescentes de vegetação nativa situados dentro ou nos limites de áreas metropolitanas, cujo papel se consubstancia como filtro climático local ou regional responsável por barrar e minimizar a expansão da polvição atmosférica, mas também as reservas naturais de preservação obrigatória e as amostras representativas de diferentes ecossistemas. Nessa categoria estariam áreas como as massas florestais da Serra do Mar, Cantareira, Jaraguá, CotiaMorro Grande, Paranapiacaba, Suindara e Bonilha, algumas dessas, segundo o autor, remanescentes de cobertura vegetal bastante maltratadas.

O segundo elemento para reconhecimento dizia respeito ao princípio de distinção que permitiria identificar, no território, as paisagens de exceção. $\mathrm{Na}$ definição dada pelo autor, essas constituem fatos isolados, com diferentes aspectos físicos e ecológicos e que se encontram inseridas no corpo geral das paisagens habituais. ${ }^{30}$ São sítios de forma natural bizarra, feições diferenciadas que se destacam na paisagem como topografias que mais parecem ruínas - o relevo ruiniforme -, pontões rochosos, esporões que avançam no mar, ilhas, formações calcárias que dão origem a grutas e cavernas e os cânions, também conhecidos regionalmente sob diversos nomes como gargantas, boqueirões, itaimbés, desfiladeiros, entre outros. As paisagens de exceção não são importantes apenas como morfologias únicas e peculiares, apreciadas pelo seu caráter estético, mas também por serem representativas de processos e dinâmicas naturais em que se cruzam as relações do mundo físico, 
geoecológico e biótico, que permitem compreender a formação física do planeta. Tem-se, assim, combinadamente o valor científico e estético-paisagístico.

O terceiro critério é o da valorização e proteção do que o autor chamou de paisagens de substituição, ou seja, as margens de lagos ou reservatórios construídos pela ação humana, velhos hortos florestais, ilhas e glebas usadas como colônias penais, fazendas e sítios do estado. Aqui se encontram exemplos como o do Horto Florestal de Rio Claro, da Itha Anchieta ou do Complexo Hospitalar do Juquery, bens tombados posteriormente pelo Condephaat. Esse terceiro critério é o que mais se distancia daquela visão da Unesco de natureza selvagem e íntegra (wildness), o que possibilita reforçar a ideia de uma natureza objeto de ação cultural, que, na década seguinte, será bastante utilizada.

A proposta de diretrizes para a proteção de áreas naturais, elaborada por Ab'Saber em 1976 e publicada em 1977, teve dois grandes méritos na trajetória de incorporação da natureza como patrimônio cultural. Em primeiro lugar, como esforço de estabelecimento de fundamentos conceituais, baseados na produção de conhecimentos acadêmicos-científicos, voltados a orientar ações do poder público, superando, assim, um tratamento pontual e esporádico, como até então se dava no órgão. Em segundo lugar, esse documento foi desencadeador de uma discussão até então inédita dentro de um órgão de preservação: a proposta de tombamento da Serra do Mar, o maior e mais complexo patrimônio natural do estado de São Paulo. Ab'Saber defendia que, em termos de área crítica e ecologicamente estratégica, o conjunto da Serra do Mar deveria ter prioridade total. Como ele escreveu tempos depois: "Estou pensando na Serra do Mar, que tem uma expressão planetária para mim [...] Não há governo no mundo que me convença de que aquilo não devesse ser tombado a nível nacional ou como patrimônio da humanidade, se possível." ${ }^{11}$

Para tratar desse assunto, o colegiado do Condephaat recebeu, um mês depois de apresentado e debatido o documento, representantes da Secretaria de Agricultura e da Coordenadoria de Pesquisas de Recursos Naturais (CPRN), que estavam estudando a proposta da criação de um parque estadual ou uma reserva florestal em área da Serra do Mar. Na ocasião esses representantes ressaltaram a importância do tombamento da serra como ato complementar de um decreto de criação de parque. ${ }^{32}$

Entretanto, passados alguns anos e com mudanças na gestão e presidência do órgão, tais iniciativas de tombamento não tiveram prosseguimento, o que somente aconteceu, a partir dos anos 1980, quando Ab'Saber se tornou presidente do órgão. Entende-se as idas e vindas na preservação das áreas naturais, nessa primeira década, como resultado do pouco interesse da instituição em relação a esse novo objeto, o que deixava as iniciativas circunscritas a ałuação individual de poucos conselheiros. 
As políticas de patrimônio cultural no estado de São Paulo, durante os anos 1980, foram profundamente marcadas pela expansão e consolidação das práticas voltadas à preservação das áreas naturais. De um lado, verifica-se a ampliação quantitativa desses objetos, como se pode constatar no gráfico 1. Comparados os tombamentos por década, observa-se que o auge da identificação e proteção se deu nos anos 1980, declinando consideravelmente nos momentos seguintes. Nos anos 1990, o número de tombamentos de áreas naturais foi cerca de 50\% inferior à década anterior e, nos anos seguintes, esse número cai abruptamente, representando um retrocesso na identificação, com número bem abaixo da década inicial. Os anos 1980, do ponto de vista quantitativo, indicam, assim, o auge na trajetória de preservação do patrimônio natural paulista.

Por outro lado, a expansão é também qualitativa, pois há inserção de novas tipologias de áreas naturais, mostrando a diversificação de objetos. Também se implementam inovações na gestão, com o atendimento de demandas sociais crescentes e a elaboração de uma normativa legal específica para orientar procedimentos em relação ao tombamento dessas áreas. O marco central das políticas nessa década foi, sem dúvida, o tombamento da Serra do Mar, por meio da Resolução SC n 40 de 6 de junho de 1985.

E o papel de Ab'Saber para a consolidação desse trabalho foi fundamental. Foram cinco meses de atuação como presidente do Condephaat, entre novembro de 1982 a março de 1983, momento em que foram retomados e finalizados processos e estudos que se encontravam até então paralisados, além de encaminhados novos tombamentos, tudo isso em um curto período. No total, o salto da gestão Ab'Saber para a preservação de áreas naturais conta com oito novos patrimônios naturais, assim como a consolidação de novas tipologias de patrimônios naturais.

Nessa gestão, o geógrafo iniciou sua participação no conselho como representante do antigo Serviço de Museus Históricos, à época Departamento Estadual de Museus e Arquivos (Dema), tendo sido indicado como presidente pelo gabinete do então Secretário da Cultura, João Carlos Martins. ${ }^{33}$ Tal indicação revela as relações políticas de Ab'Saber que Ihe garantiram a agilidade necessária para encaminhamento de diversas decisões.

Entre elas, os tombamentos realizados em sua gestão foram quatro: Unidades de Habitação de Picinguaba (Ubatuba), Serra do Japi, Guaxinduva e Jaguacoara (Jundiaí, Cabreúva, Pirapora do Bom Jesus e Cajamar), Mata Santa Genebra (Campinas) e Parque Estadual do Jaraguá (capital). 
Gráfico 1 - Patrimônio Natural tombado (1969-2016) pelo Condephaat,

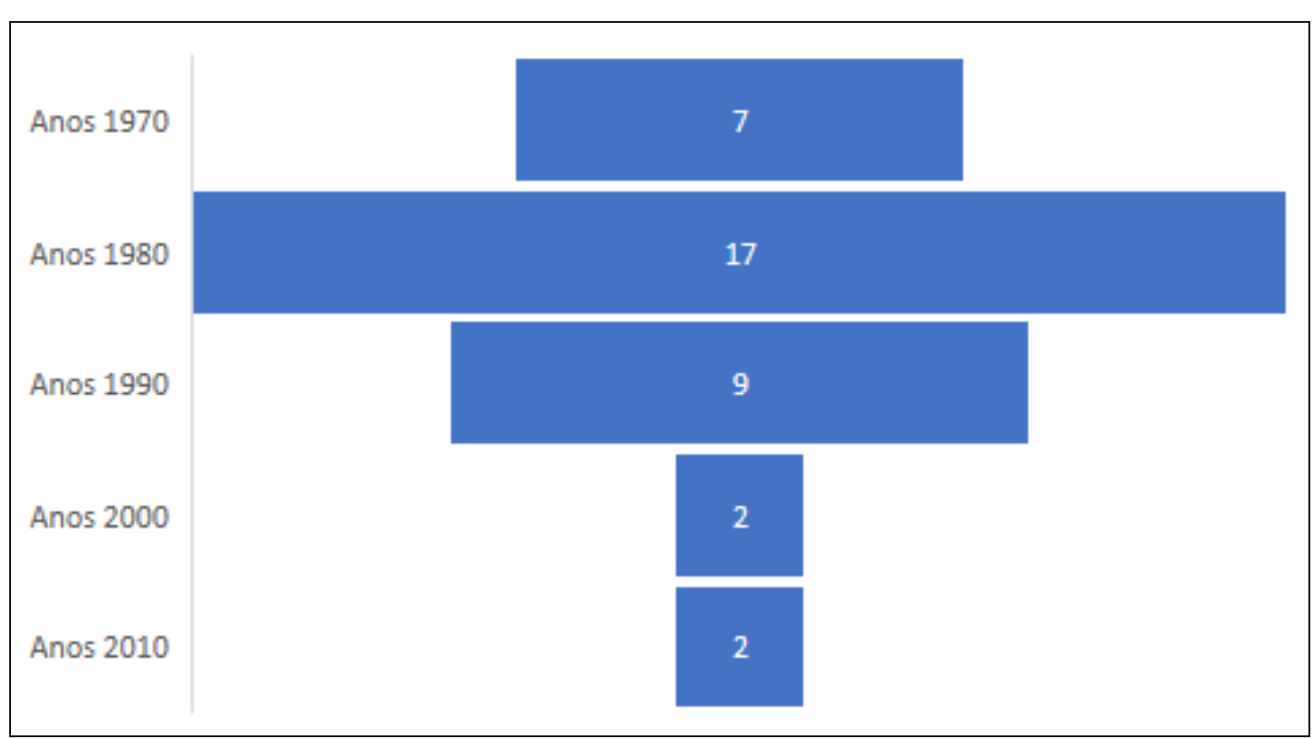

Fonte: elaboração própria, a partir de Scifoni (2006) e Infraestrutura de Dados... (2020).

tombamento da vila de pescadores de Picinguaba é um desses exemplos de longa tramitação de processos. O pedido, encaminhado em 1976, foi aprovado nesse mesmo ano com voto favorável do conselheiro Ab'Saber, que alertava para a necessidade de se preservar a diversidade de modos de ocupação no litoral, como é o caso das vilas caiçaras, com sua ocupação rústica nos cantos e pontas de praias, em virtude das ameaças representadas pela expansão de um modelo especulativo e, também, monótono e agressivo de loteamentos de segundas residências. ${ }^{34}$ Entretanto, o processo permaneceria durante anos sem finalização. Seu desfecho final deu-se durante a gestão de Ab'Saber, com a assinatura da resolução de tombamento pelo Secretário de Cultura. A inclusão desse bem como área natural deu-se em função da compreensão de que o objeto de tombamento, a vila caiçara, estava intimamente relacionada às condições naturais ali presentes. A compreensão da relação indissociável entre a cultura, modo de vida dessas populações tradicionais de pescadores artesanais e a natureza, levou à delimitação de uma poligonal de tombamento ampliada, que incluía a vila e suas habitações, uma parte da Praia da Fazenda, parte do Morro de Picinguaba, o Rio das Bicas e algumas ilhas frontais à Baía de Picinguaba. ${ }^{35}$

Já o tombamento da Serra do Japi, Guaxinduva e Jaguacoara foi um marco pelo desafio e complexidade do conjunto de serras, o que exigiu um desenho de preservação inteiramente novo. A forma assimétrica do conjunto dificultava a utilização de cotas altimétricas como critério de delimitação, o que vinha sendo usado, por

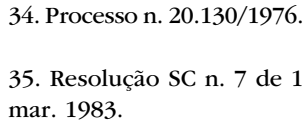
mar. 1983. 
36. Resolução SC n. 14 de 6 jul. 1983.

37. Resolução SC n. 11 de 8 mar. 1983. exemplo, no tombamento do Maciço da Jureia. Nesse sentido, Ab'Saber inovou ao definir uma poligonal irregular, delimitada a partir de pontos georreferenciados em coordenadas geográficas, o que viabilizou incluir na área tombada um conjunto de serras e um mosaico de ecossistemas (figura 3). Essa experiência foi repetida, na sequência, em outros dois tombamentos: o da Serra do Boturuna e o da Serra de Atibaia. A poligonal geométrica definida a partir de coordenadas geográficas, em todos esses casos, permitia delimitar e circunscrever o corpo principal desses acidentes topográficos e geológicos. No caso de Atibaia, a poligonal geométrica (figura 4) visava incluir três unidades de formas de relevo identificadas: o domo da Pedra Grande, a face da serra voltada para oeste e os baixos patamares de piemonte. ${ }^{36}$ No caso do Boturuna, a poligonal viabilizou circunscrever o corpo principal da pequena serra e deixar como área envoltória os baixos patamares e colinas que a envolvem (figura 5).

Outra inovação resultante do tombamento da Serra do Japi foi o conjunto de diretrizes de ocupação da área tombada, que procurou orientar uma série de usos e atividades preexistentes como exploração agrícola, pecuária, reflorestamento, mineração, usos ligados ao lazer, implantação de infraestrutura, parcelamento e loteamento de terras e projetos turísticos. ${ }^{37}$ A resolução de tombamento da Serra do Japi tornou-se tão importante que acabou sendo modelo a ser seguido em tombamentos que vieram posteriormente. Dentre outros processos agilizados e finalizados em sua gestão, encontram-se mais quatro: Reserva Estadual da Cantareira e Horto Florestal (capital/Mairiporã), Serra de Atibaia ou Itapetinga (Atibaia/Bom Jesus dos Perdões),

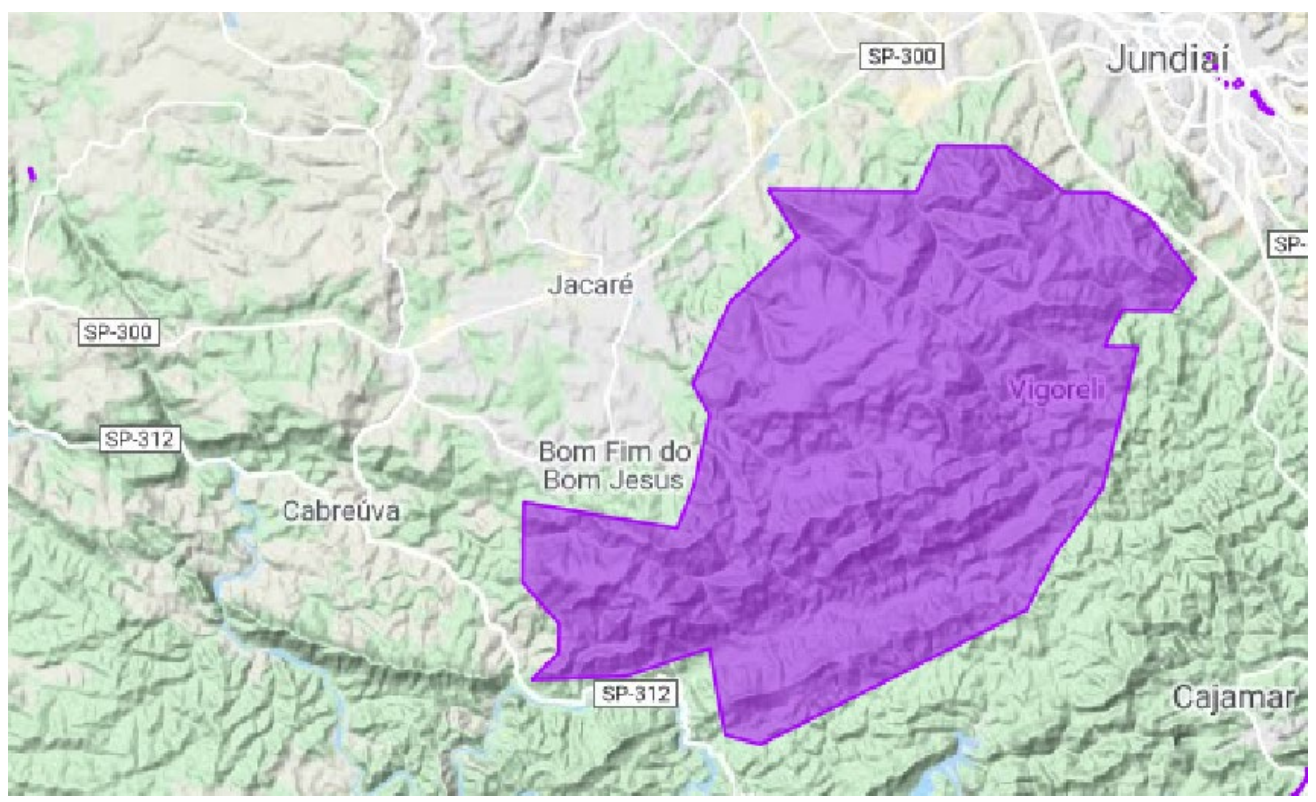

Figura 3 - Poligonal de tombamento da Serra do Japi. Fonte: Infraestrutura de Dados... (2020). 
Serra do Boturuna (Pirapora do Bom Jesus, Santa do Parnaíba e São Roque) e a própria Serra do Mar (vários municípios), exemplos que mostram a ênfase dada em sua gestão para a consolidação dessa tipologia de patrimônio natural tombado, em função de suas pesquisas na área de geomorfologia.

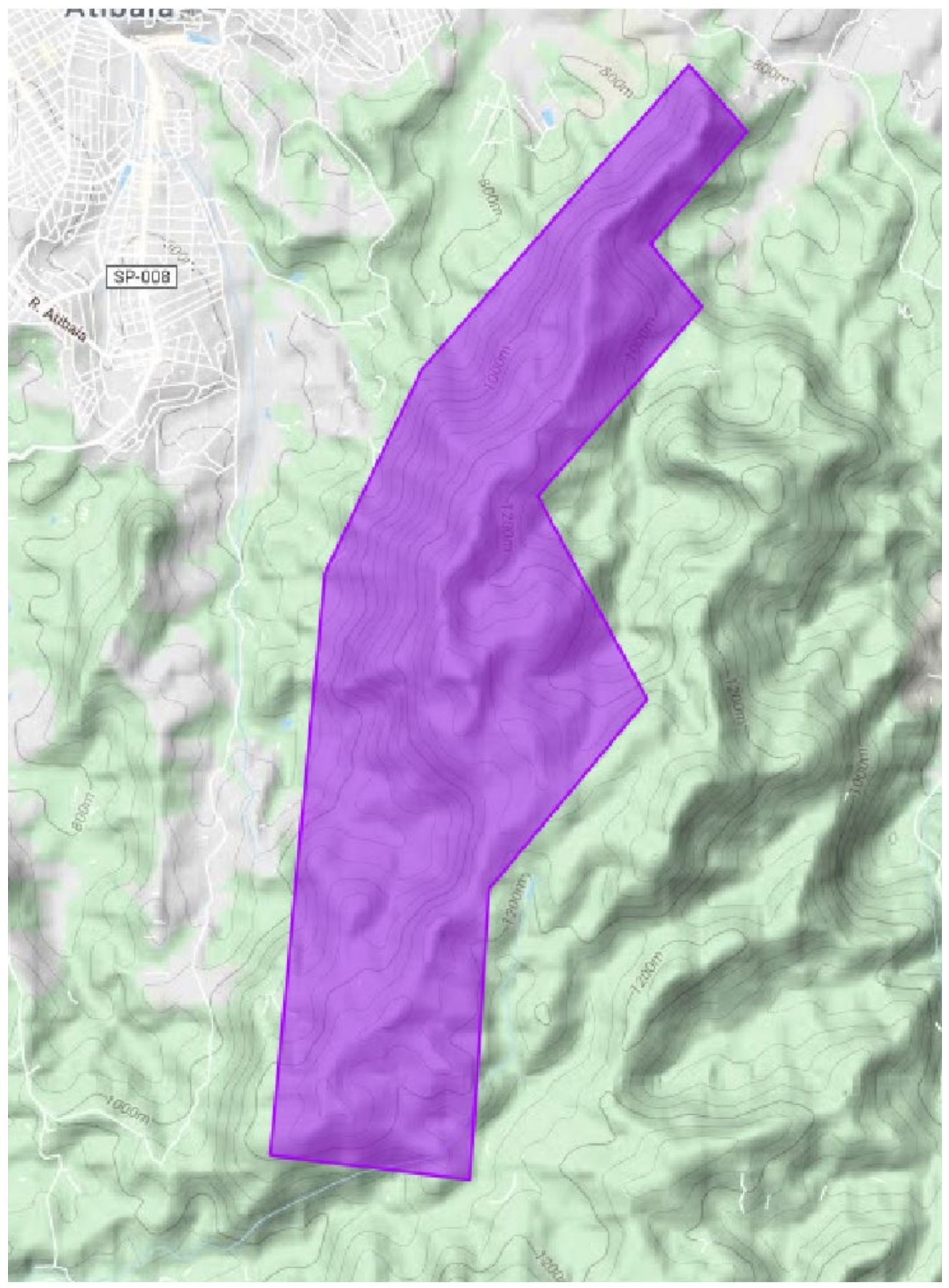

Figura 4 - Poligonal de tombamento da Serra de Atibaia. Fonte: Infraestrutura de Dados... (2020). 


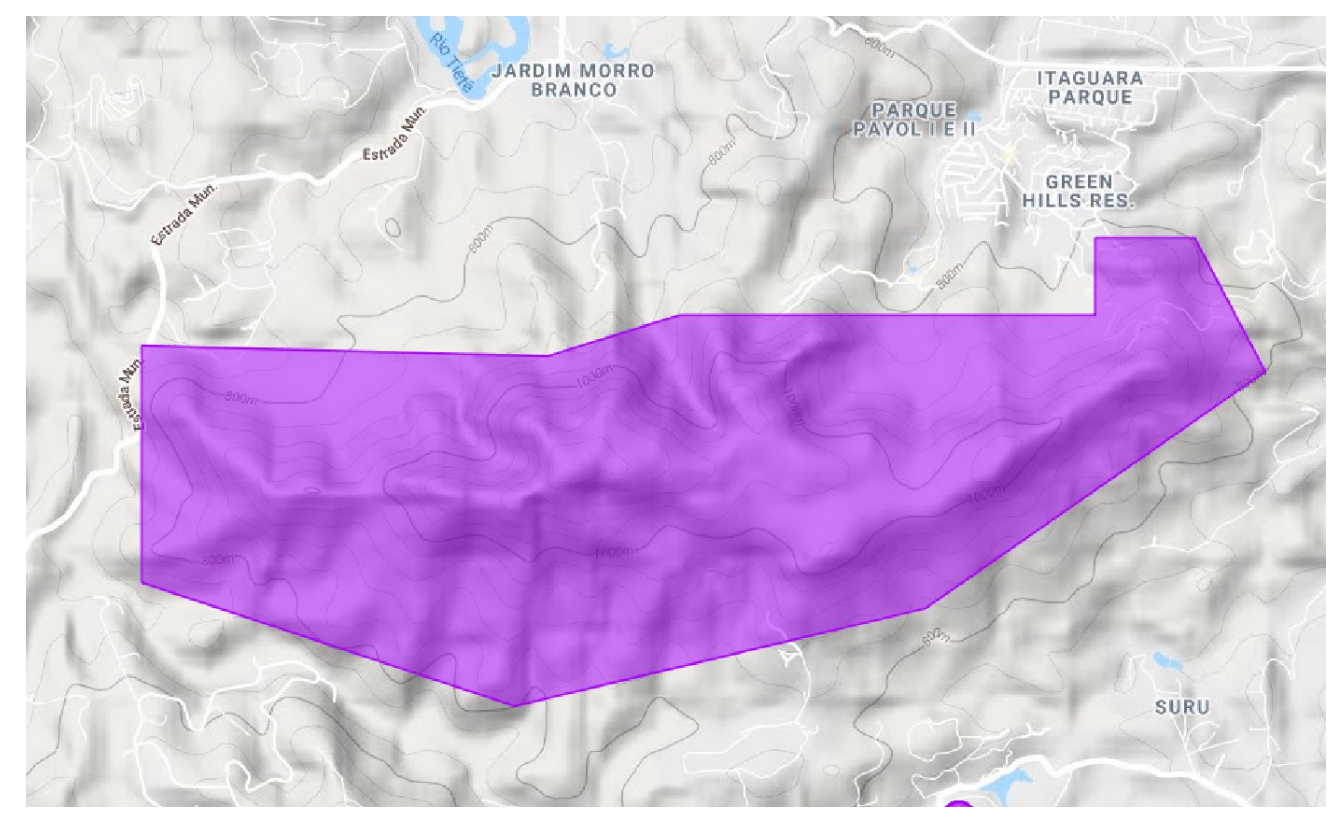

Figura 5 - Poligonal de tombamento da Serra do Boturuna. Fonte: Infraestrutura de Dados... (2020).

Essa ampliação quantitativa, indicada anteriormente pelo gráfico 1, é acompanhada de mudanças qualitativas, no que diz respeito à consolidação de novas tipologias de bens naturais e a ampliação de sua representatividade no território paulista, com uma interiorização da ałuação.

quadro 2, a seguir, mostra as tipologias que vão configurando o conjunto do patrimônio natural tombado, algumas das quais se consolidam nesse período, tendo grande expansão. Esse é o caso dos parques e áreas verdes urbanas, que tiveram mais três bens tombados, como a Reserva da Cantareira, o Parque da Aclimação e a Casa Modernista, além da tipologia morros e serras que se expandiram bastante em número, contando com mais seis áreas, as Serras do Japi, de Atibaia, do Boturuna, o Morro do Botelho e a Serra do Mar. Outras continuam como exemplos bem circunscritos, caso das paisagens-complemento, envoltórias de monumentos ou edificações e mananciais, que nesse período conta com mais uma, o entorno da Vila de Paranapiacaba. Novas tipologias aparecem como mananciais, caso do Vale do Quilombo e dos bairros-jardins, formado pelo conjunto jardim Europa, Paulista e Paulistano. Outras tipologias não terão expansão nessa década, é o caso dos monumentos geológicos. 
Quadro 2 - Patrimônios naturais tombados pelo Condephaat (anos 1980)

\begin{tabular}{|l|l|}
\hline Bem tombado (município) & $\begin{array}{l}\text { Ano } \\
\text { (resolução de } \\
\text { tombamento) }\end{array}$ \\
\hline Reserva Florestal do Morro Grande (Cotia) & 1981 \\
\hline Jardim da Luz (capital) & 1981 \\
\hline Parque Siqueira Campos (capital) & 1982 \\
\hline Mata Santa Genebra (Campinas) & 1983 \\
\hline Vila de Picinguaba (Ubatuba) & 1983 \\
\hline Parque Estadual do Jaraguá (capital) & 1983 \\
\hline Serras do Japi, Guaxinduva e Jaguacoara (Jundiaí, Cabreúva, Pirapora do Bom Jesus) & 1983 \\
\hline Serra de Atibaia (Atibaia e Bom Jesus dos Perdões) & 1983 \\
\hline Serra do Boturuna (Pirapora do Bom Jesus, Santana do Parnaíba e São Roque) & 1983 \\
\hline Reserva Est. Cantareira e Horto Florestal (Caieiras, Guarulhos, Mairiporã e capital) & 1983 \\
\hline Morro do Botelho (Guarujá) & 1984 \\
\hline Serra do Mar (43 municípios) & 1985 \\
\hline Morros do Icanhema, do Pinto e do Monduba (Guarujá) & 1985 \\
\hline Parque da Aclimação (capital) & 1986 \\
\hline Jds. América, Europa, Paulista e Paulistano (capital) & 1986 \\
\hline Casa Modernista (capital) & 1986 \\
\hline Vila de Paranapiacaba (Santo André) & 1987 \\
\hline Vale do Quilombo (Cubatão) & 1988 \\
\hline
\end{tabular}

Fonte: elaboração própria, a partir de Scifoni (2006).

Outra dimensão qualitativa das mudanças diz respeito às inovações na gestão. Uma delas, o mais importante legado da década de 1980, é a aproximação do órgão com a sociedade, no sentido de atendimento aos pedidos de tombamento de áreas naturais. Nessa década a demanda por tombamento desses bens mais que duplicou em relação ao momento anterior, eram pedidos que partiram de movimentos ambientalistas, associações de profissionais e sociedade amigos de bairros, entre outras. Dentre as razões que justificam os pedidos, encontram-se a redução de áreas verdes urbanas, de uso público ou coletivo, as pressões do mercado imobiliário, a expansão de atividade mineradora, entre outros riscos ao patrimônio.

Dessa forma, o tombamento se configurou como forma de garantir o uso e a apropriação social de espaços da cidade, de proteger a paisagem ou locais 
38. Ordem de Serviço $2 / 1982$. que constituem referências à memória de grupos sociais e, portanto, como importante conquista social, que a Constituição Federal de 1988 posteriormente referendou. Ao se mobilizarem pela defesa desses patrimônios, os grupos sociais se tornam sujeitos da preservação que inventam suas próprias táticas de luta e de organização, demandando ação do Estado, o que acaba por fortalecer a imagem do órgão. $\bigcirc$ patrimônio natural, nesse sentido, manifesta-se como algo que é conquistado por meio da luta e da mobilização, configurando uma noção ligada às práticas sociais e à memória coletiva, portanto, um patrimônio cuja legitimidade passa pelo valor social e afetivo, já que faz parte do cotidiano e da vida social.

Um importante exemplo disso foi a mobilização em torno da preservação da área verde da Casa Modernista. $\bigcirc$ terreno, em eminência de ser vendido a uma construtora para serem erguidos edifícios residenciais, foi alvo de uma luta dos moradores do bairro da Vila Mariana que tinham uma forte relação afetiva e de memória com o bosque. A perda dessa área verde que fazia parte da história do bairro e da memória dos moradores associava-se também à perda da tranquilidade e das condições originais do entorno. Lutar pelo tombamento era uma forma de lutar pelo bairro, pelos referenciais de memória e identidade, pela sua singularidade, mas também de questionar a lógica de produção do espaço urbano, que transforma tudo em mercadoria, pasteuriza, uniformiza.

Como parte das inovações na gestão que configuram as mudanças qualitativas dessa década, destaca-se, ainda, a instituição de uma normativa específica voltada às áreas naturais com o objetivo de orientar as ações do órgão que, somada à fundamentação conceitual estabelecida por Ab'Saber, na década anterior, configura os pilares fundamentais da trajetória da preservação do patrimônio natural.

Essa normativa, publicada em 1982, ${ }^{38}$ foi elaborada por uma comissão de conselheiros e especialistas convidados em um documento chamado "Subsídios para um Plano Sistematizador das Paisagens Naturais do Estado de São Paulo". Conforme consta no texto da normativa, fizeram parte dessa comissão Lea Goldenstein, coordenadora, Gil Sodero de Toledo, João Régis Guillaumon, José Pedro de Oliveira Costa, Maria Helena de Almeida Mello e Rodolfo Geiser. Partindo da noção de paisagem, já que a lei garantia ao Condephaat a atribuição de proteção dos recantos paisagísticos, essa normativa estabelecia uma lista de sete objetos de interesse para fins de tombamento: formas de vegetação nativa remanescentes, em especial em áreas onde essa cobertura esteja ameaçada de extinção; vegetação secundária de valor científico ou em função da condição de escassez das originais; monumentos geológicos, feições geomorfológicas ou pedológicas particulares; mananciais; áreas que constituam habitat de espécies de fauna raras; paisagens mesmo que alteradas, mas que se 
destacam pela expressividade, raridade ou mesmo beleza excepcional, além daquelas representativas de interesse turístico, científico ou social.

A importância da normativa foi, assim, ampliar o entendimento daquilo que era considerado paisagem e, consequentemente, patrimônio natural, para além de seus atributos estéticos que eram os mais enfatizados na década anterior. Para Furlan, ${ }^{39}$ isso significou que:

O princípio geral da proteção de áreas naturais pelo estatuto do tombamento foi proteger a paisagem como espaço total de remanescentes com as marcas culturais, protegendo o que não deve ser "apagado" pela supremacia dos interesses exclusivamente econômicos que, na aceleração do mercado, rapidamente eliminam as paisagens lentas, significativas e relevantes. A aceleração contemporânea elimina as marcas históricas, geomorfológicas, biogeográficas e culturais. Foi uma visão fortemente inovadora para o patrimônio e do vínculo com a cultura viva, a mais viva possível.

Por fim, o marco das ações públicas nos anos 1980 para as áreas naturais foi o tombamento da Serra do Mar, efetivado a partir da gestão de Ab'Saber como presidente. Como foi visto anteriormente, a discussão inicial a respeito do tombamento não se desdobrou em ações concretas após 1977, até que em fevereiro de 1983, na gestão do geógrafo, o assunto é retomado e encaminhado para elaboração de parecer técnico pelo assessor Mauro Antônio de Moraes Victor, indicado por Ab'Saber. parecer elenca pelos menos 14 razões para o tombamento da Serra do Mar ${ }^{40}$ e é aprovado em reunião do colegiado em fevereiro de $1983,{ }^{41}$ o que significou a abertura de processo de tombamento, equivalente ao tombamento provisório na legislação federal, garantindo a preservação até a decisão final do conselho.

Frente à presidência do Condephaat, Ab'Saber ficou apenas alguns meses, o que the impediu de acompanhar a continuidade do processo. Na sequência, em 1984 iniciaram-se os estudos visando a delimitação da poligonal de tombamento que incluiu entre os limites o Parque Estadual da Serra do Mar, trechos de planície arenosas, mangues, praias, esporões, morros isolados e ithas, grosso modo acompanhando a cota altimétrica de 40 metros. Também naquele momento foi estabelecido um conjunto de 16 diretrizes gerais para a área tombada. Levada a proposta ao conselho, em abril de 1985, aprovou-se o tombamento definitivo, com a delimitação proposta pela equipe técnica, o que levou Ab'Saber a tecer críticas contundentes em artigo publicado na Revista do Patrimônio Histórico do lphan. ${ }^{42}$ A divergência dizia respeito à concepção do desenho da área tombada, que, para ele, não deveria ter tomado como base os limites institucionais dos parques. Para ele era necessário garantir a proteção de uma faixa de dois a três quilômetros do topo da escarpa em direção ao reverso continental, para garantir a integridade física. Na planície, para o geógrafo, era necessária uma
39. Cf. Furlan (2018).

40. Cf. Crispin (2016)

41. Ata 544 de 22 fev. 1983, processo Condephaat $\mathrm{n}$. 20.868/1979.

42. Cf. Ab'Saber (1986). 
zona tampão de extensão variada, conforme as particularidades topográficas de cada subsetor da serra, estabelecendo zonas totalmente restritivas para mangues, estirâncios de praias, falésias, estuários, lagunas e campos de dunas.

O tombamento da Serra do Mar não foi o primeiro instrumento legal para a proteção da natureza no litoral, já que the antecedeu a criação de diversos parques estaduais, tanto no litoral norte e central como no sul. Entretanto, o tombamento inaugurou uma perspectiva de proteção da natureza mais ampla, com foco na paisagem como um conjunto articulado de elementos. Não se tratava apenas da cobertura vegetal ou as nascentes de rios, mas uma unidade fisiográfica global (figura 6), o mais contínuo e monumental acidente geológico-geomorfológico da América do Sul, testemunho do soerguimento da borda do Planalto Atlântico. ${ }^{43}$

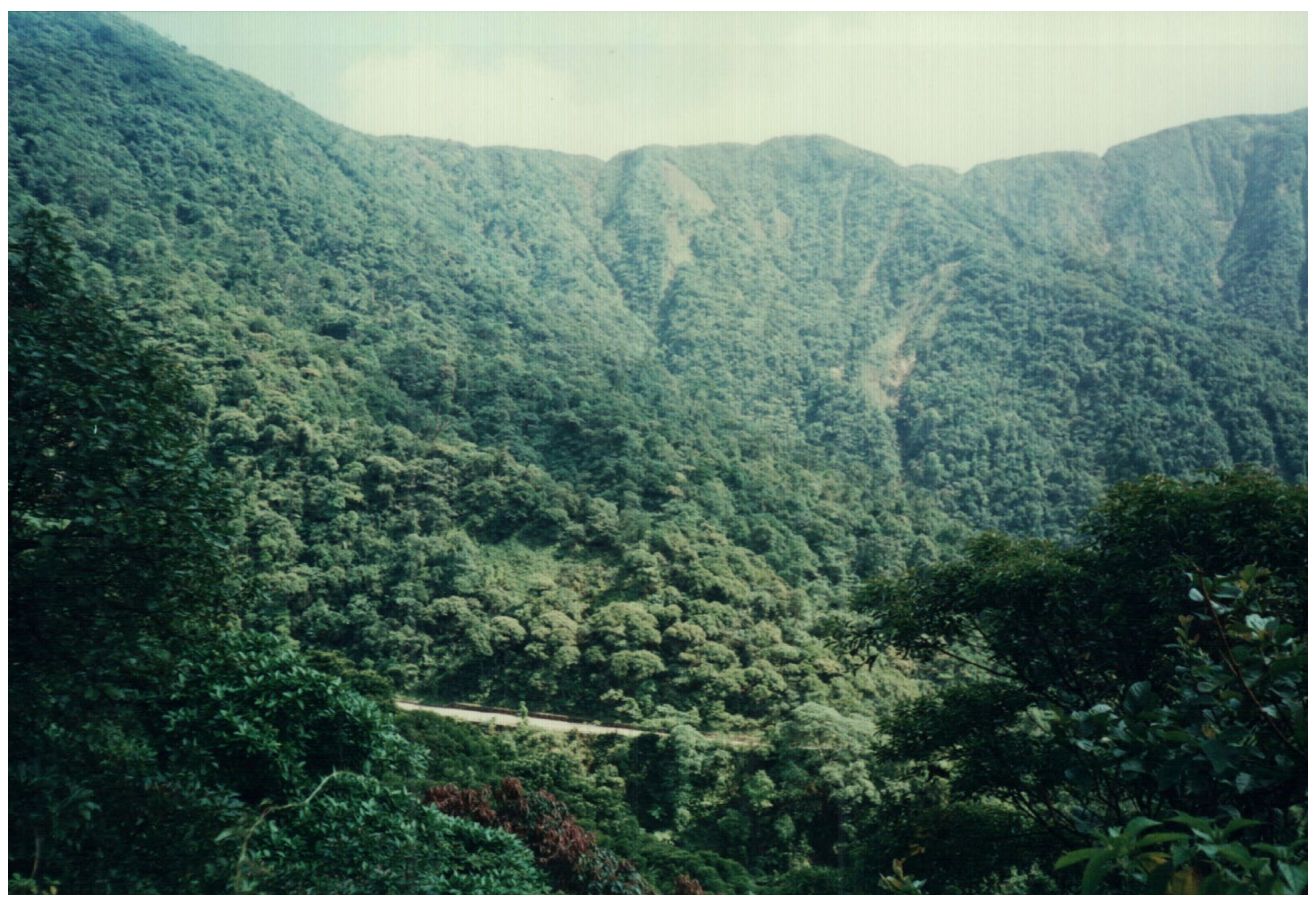

Figura 6 - Aspecto da Serra do Mar, em trecho do município de Cubatão. Observa-se a ocorrência de cicatrizes de deslizamentos nas encostas que evidenciam a sua fragilidade ambiental, 2000. Foto: arquivo pessoal.

Por sua grande extensão, englobando terras de 44 municípios paulistas e somando uma área de 1,3 milhão de hectares, o tombamento da Serra do Mar se tornou objeto de árduas discussões à época, já que se desdobrou em outros pedidos de tombamento, no então Sphan e em órgãos estaduais no Paraná e Rio de Janeiro. A Revista do Patrimônio Histórico e Artístico Nacional foi um dos lugares preferenciais de debates, tendo sido objeto de, pelo menos, duas edições, $n^{\circ} 21$, 
de 1986, com dois textos dedicados ao tema, um deles de autoria de Ab'Saber, e a edição $n^{\circ} 22$, de 1987, que registrou uma mesa-redonda sobre patrimônio natural, com vários textos e uma seção inteira dedicada ao tema.

Em 1985, o ato oficial de tombamento contou com a presença do então governador do estado de São Paulo, o que conferiu importância e peso político ao instrumento do tombamento e ao próprio Condephaat. Na ocasião, Franco Montoro se manifestou, afirmando que "ninguém mexerá na Serra do Mar sem dar satisfação ao estado e à comunidade". ${ }^{44}$

\section{CONSIDERAÇÕES FINAIS}

Não obstante a importância desse legado da década de 1980 para a preservação de áreas naturais, o que se constata, nos anos seguintes, é o enfraquecimento e dissolução desse trabalho. Os dados do gráfico 1, anteriormente apresentado, mostram que, na década de 1990, o número de áreas naturais tombadas começa a cair em relação aos anos anteriores, de 17 para 9, representando uma redução de cerca de 50\% e, principalmente, nos últimos vinte anos, quando a redução foi ainda mais drástica, com apenas dois bens tombados por década.

A redução não é apenas numérica, mas é sintoma de um processo mais amplo que pode ser denominado de desregulamentação do patrimônio natural ${ }^{45}$ e que envolveu diferentes estratégias políticas, como a redução e a eliminação da possibilidade de tombamento de outros patrimônios naturais, o que explica a queda dos números. Essa estratégia política parte do questionamento sobre a atribuição do órgão em relação à proteção das áreas naturais, afirmando uma suposta sobreposição de tutelas entre o Condephaat e os órgãos ambientais. Nesse sentido, no curso da desregulamentação, pouco a pouco, os pedidos de tombamento vão sendo paralisados ou rejeitados, com a argumentação de ausência de competência legal, ignorando-se até mesmo a Constituição Federal, em seu artigo 216 , reproduzido na equivalente lei estadual. Outro argumento utilizado é da incapacidade técnica para dar encaminhamento a essas solicitações por ausência de profissionais especializados, problema que persiste nas duas últimas décadas sem solução. Algumas exceções acabam escapando ao curso da desregulamentação das duas últimas décadas, como se observa no quadro 3. 


\section{Quadro 3 - Patrimônios naturais tombados pelo Condephaat (2000-2019)}

\begin{tabular}{|l|l|}
\hline Bem tombado (município) & Ano (resolução de tombamento) \\
\hline Cratera de Colônia & 2003 \\
\hline Morro Juquery & 2004 \\
\hline Serra de Itaqui & 2016 \\
\hline Parque Estadual Fontes do Ipiranga & 2018 \\
\hline
\end{tabular}

Fonte: elaboração própria, a partir de Infraestrutura de Dados... (2020).

Outra estratégia política adotada na desregulamentação tem sido a alteração pontual ou integral de várias normativas de tombamento de áreas naturais, que atingiu, inclusive, a de tombamento da Serra do Mar. As estratégias buscam superar o que é visto como barreira e obstáculo do patrimônio natural à realização da produção do espaço como mercadoria e negócio lucrativo.

argumento utilizado por gestores do poder público e por aqueles que se encontram mergulhados na defesa desses interesses econômicos tem sido a necessidade de atualização da legislação, álibi para que se promovam intervenções pontuais ou mais extensas na legislação reguladora desses tombamentos. Assim sendo, o obstáculo primeiro a ser removido é a base legal, ou seja, as normativas e resoluções de tombamento que inviabilizam ou restringem a atuação do setor econômico, como projetos e planos de expansão do mercado imobiliário. Nesse sentido, constatam-se alterações pontuais, de artigos dessas normativas que dizem respeito a diretrizes ou até a definição de poligonais de tombamento ou, também, intervenções mais enérgicas como a eliminação integral das normas, caso do tombamento da Serra do Mar. A desregulamentação do tombamento da Serra do Mar, que ocorreu em 2000 a partir do arquivamento das Normas, Diretrizes e Recomendações Preliminares, estabelecidas em 1987, deixou uma área tombada de 1,3 milhão de hectares ao sabor de análises pontuais, caso a caso, a depender de interesses individuais.

O processo de desregulamentação, ao longo de duas décadas, se generalizou para todo o conjunto do patrimônio cultural paulista, não se restringindo somente às áreas naturais, sendo sua culminância ocorrida, recentemente, em 2019, com a redução drástica dos representantes das universidades públicas paulistas no conselho, a partir da publicação do Decreto Estadual no 64.186, de 16 de abril de 2019,46 que alterou a composição do Condephaat. O recente Dossiê Condephaat 50 anos, publicado na edição especial da Revista CPC, em 2018, buscando atualizar o debate sobre as ações do órgão, mostrou alguns problemas que compõem 
o universo da chamada desregulamentação: destombamentos, arquivamento de processos, aprovações de intervenções desrespeitando aspectos legais e a própria expertise do campo. Por outro lado, mostrou, também, que é preciso avançar na produção de conhecimento e na reflexão crítica tão necessária a construção de possibilidades de superação dessa problemática.

Em 50 anos de atuação, depois de tantas conquistas dos anos 1980, como a aproximação com a sociedade, a ampliação conceitual que permitiu a inclusão de novos objetos e os avanços das normativas e práticas na gestão, o Condephaat do século XXI mostra estar em sua pior fase, refém de interesses políticos e econômicos, esvaziado de conteúdo crítico-reflexivo e rejeitando a contribuição do conhecimento acadêmico que permite avaliar, problematizar e avançar. $E$, principalmente, distante dos anseios da sociedade no atendimento ao patrimônio como realização do direito à memória. Como lembrava Ab'Saber, na década de 1980:

Não são os governos que tomam a iniciativa do tombamento. As solicitações quase sempre partem dos cidadãos esclarecidos. Ou de grupos comunitários. Ou, ainda de estudiosos sensibilizados pela ideia de proteger o patrimônio da Sociedade e da Nação, de modo inteiramente idealista e desinteressado. Em contraposição às eternas expectativas de lucros dos especuladores de todos os naipes. ${ }^{47}$ 


\section{REFERÊNCIAS}

FONTES DOCUMENTAIS MANUSCRITAS

ATA n. 287 de Reunião do Condephaat, 14 jun. 1976.

ATA da Reunião do Condephaat, 27 jul. 1977.

ATA n. 544 de Reunião do Condephaat, de 22 fev. 1983.

CARTA Aberta de Repúdio ao Decreto Estadual 64.186, de 16 abr. 2019.

PROCESSO Condephaat n. 9.884/1969. Tombamento da Pedreira de Varvito, Itu, 1969.

PROCESSO Condephaat n. 123/1972. Tombamento do Caminho do Mar, Cubatão, 1972.

PROCESSO Condephaat n. 00306/1973. Tombamento do Maciço da Jureia, Iguape, 1973.

PROCESSO Condephaat n. 00428/1974. Tombamento do Horto de Rio Claro, Rio Claro, 1974.

PROCESSO Condephaat n. 20.089/1976. Tombamento da Serra do Mar, vários municípios, 1976 .

PROCESSO Condephaat n. 20.130/1976. Tombamento das Unidades habitacionais de Picinguaba, Ubatuba, $1976 b$.

SECRETARIA DE ESTADO DA CULTURA/CONDEPHAAT. Folheto do Tombamento da Serra do Mar, 1985.

LEGISLAÇÃO

BRASIL. Decreto-lei $n$. 25, de 30 de novembro de 1937. Organiza a proteção do patrimônio histórico e artístico nacional.

BRASIL. Constituição da República Federativa do Brasil, 1988. 
BRASIL. Decreto Federal n. 3, de 13 fev. 1948, que referendou a Convenção para a Proteção da Flora, da Fauna e das Belezas Cênicas Naturais dos países da América.

SÃO PAUlO (Estado). Constituição do Estado de São Paulo, 1967.

SÃO PAULO (Estado). Lei Estadual n. 10.247, de 22 out. 1968. Dispõe sobre a competência, organização e funcionamento do Condephaat.

SÃO PAULO (Estado). Decreto-lei complementar n. 2, de 15 ago. 1969. Estabelece normas para a proteção das belezas de interesse turístico.

SECRETARIA DE ESTADO DA CULTURA/CONDEPHAAT. Ordem de Serviço 02/1982. Subsídios para um Plano Sistematizador das Paisagens Naturais de São Paulo.

SECRETARIA DE ESTADO DA CULTURA/CONDEPHAAT. Resolução de 9 abr. 1970. Tombamento do Bosque dos Jequitibás.

SECRETARIA DE ESTADO DA CULTURA/CONDEPHAAT. Resolução de 2 abr. 1975. Tombamento do sítio onde se deu o Grito do Ipiranga.

SECRETARIA DE ESTADO DA CULTURA/CONDEPHAAT. Resolução n. 7 de 1 mar. $1983 a$. Tombamento dos Aglomerados Humanos de Picinguaba.

SECRETARIA DE ESTADO DA CULTURA/CONDEPHAAT. Resolução n. 11 de 8 mar. 1983 b. Tombamento das Serras do Japi, Guaxinduva e Jaguacoara.

SECRETARIA DE ESTADO DA CULTURA/CONDEPHAAT. Resolução n. 14 de 6 jul. 1983c. Tombamento da Serra de Atibaia ou Itapetinga.

LIVROS, ARTIGOS E TESES

AB'SABER, Aziz Nacib. Diretrizes para uma política de preservação de Reservas Naturais do Estado de São Paulo. São Paulo: Instituto de Geografia/USP, 1977 (Série Geografia e Planejamento).

AB'SABER, Aziz Nacib. Potencialidades naturais da Fazenda Rio Verde: estudo prévio. In: Condephaat. Processo no 00306/1973. Tombamento do Maciço da Jureia, Iguape, p.41-46.

AB'SABER, Aziz Nacib. O tombamento da Serra do Mar. Revista do Patrimônio Histórico e Artístico Nacional, Brasília, n. 21, p. 6-19, 1986. 
AB'SABER, Aziz Nacib. Escritos ecológicos. São Paulo: Lazuli Editora, 2006.

CHAUI, Marilena. Brasil. Mito fundador e sociedade autoritária. São Paulo: Fundação Perseu Abramo, 2013.

CRISPIN, Felipe Bueno. Entre a geografia e o patrimônio. Estudo das ações de preservação das paisagens paulistas pelo Condephaat (1969-1989). São Bernardo do Campo: UFABC, 2016.

FURLAN, Sueli. Áreas naturais tombadas e a proteção da paisagem. Revista CPC, v. 13, n. 26esp, p. 63-93, 4 jan. 2019.

KAMIDE, Edna Hiroe M.; PEREIRA, Teresa Cristina. E. (org.) Patrimônio Cultural Paulista: Condephaat, bens tombados 1968-1998. São Paulo: Imprensa Oficial do Estado, 1998.

RODRIGUES, Marly. Imagens do passado: a instituição do patrimônio em São Paulo 1969-1987. São Paulo: Unesp, 2000.

SCIFONI, Simone. A construção do patrimônio natural. 2006. Tese (Doutorado em Geografia) Faculdade de Filosofia, Letras e Ciências Humanas, Universidade de São Paulo, São Paulo, 2006.

URBAN, Teresa. Missão (quase) impossível: aventuras e desventuras do movimento ambientalista no Brasil. São Paulo: Peirópolis, 2001.

XAVIER, Ana Maria; SCIFONI, Simone. Patrimônio natural: 3 roteiros em São Paulo. São Paulo: Via das Artes, 2011.

SITES

INFRAESTRUTURA DE DADOS ESPACIAIS DO ESTADO DE SÃO PAULO (IDESP). Disponível em: <http://www.idesp.sp.gov.br/>. Acesso em: 7 jan. 2020.

Artigo apresentado em 10/01/2020. Aprovado em 07/05/2020. (cc) BY

All the contents of this journal, except where otherwise noted, is licensed under a Creative Commons Attribution License 